\title{
Performance, Paradigms of Visual Culture and The Matrices of Representation: Anna Deavere Smith's on The Road
}

\section{C.S.Biju}

Assoc. Professor in English \& Coordinator

Dept. of Media Studies

St. Thomas College

Thrissur, Kerala, India

csbijustc@gmail.com

\section{Abstract}

This paper attempts to put radically in to question the hegemonic choices of representation in western visual culture by examining Anna Deavere Smith's performance series On the Road: A Search for American Character. What is brought to the sharp focus of this study is the logic of perpetuating the conventional categories of race, ethnicity, gender and age in performance - a logic that prevails in the mainstream media; more specifically in theatre - and the unmasking of these categories in representation.

Then with a shout we rushed upon him and locked our arms about him; but the ancient god had not forgotten his craft and cunning. He became in turn a bearded lion, a snake, a panther, a monstrous boar; then running water, then a towering and leafy tree, but we kept our hold, unflinching and undismayed, and in the end this master of dreaded secrets began to tire. So he broke into speech ... .

The Odyssey IV, $384 \mathrm{ff}$.

Proteus, the ancient sea-deity, granted Menelaus a way of escape from the Egyptian Island of Pharos after successive transformations into a number of natural forms. With a 
Protean mastery, Performer Anna Deavere Smith puts herself into the shoes of real life characters of a community in pursuit of resolutions at a moment of crisis.

When Smith performs real life characters after interviewing them and editing their utterances with simple costume changes and histrionic transformations, the spectators including the interviewees themselves experience subtle transcendence of boundaries of race, gender, sexuality, age and class. These category crossings through the transracial, transgender performatives are crucial in defining a contemporary, progressive, cultural politics of visual culture for it contests all hegemonic practices of representation.

In conjuring up the extreme fluidity of contemporary social, cultural and political identities, Smith employs a rigorous sort of slippery identity through shape-shifting and morphing on the stage. The performative logic of Smith's work lies in her ability to create mobile identities enmeshed within clan, religion, age, region, class and dialect. The staccato language, the non-consequential logic of narrative, rapid disjunctions and shifts make the production of unitary and coherent identities in performance impossible.

Smith re-presents her subjects at the interface of genders, class and race differences by unravelling the subjectivities on the stage. The subject in performance is a floatingsubject, which escapes the shackles of modernist and essentialist logic. This results in opening up the spectator's critical faculties to a plethora of interpretations and numberless resolutions. Hence, Smith's performing field is an eccentric space, both inside and outside the historical constructs of sexual, gender and radical identities. In essence, Smith's performances invite the spectator to both theorise and problematise identities by thwarting any effort to arrive at ideological or biological conclusions. This is most evident in her total demystification and subversion of sexist and racist stereotyped representations produced and imposed by hegemonic systems of culture to perpetuate itself. These provocatively 
ambiguous, multifaceted and open-ended performances both challenge and undermine such representational practices.

Smith's decade-long performance project On the Road: A Search for American Character pivots around certain epistemological and political concerns regarding representation of racial and gender. The complexities of post capitalist economic surroundings, post civil rights ethos, anti-affirmative action campaigns, increased racial mixing, rapid shifts in immigration policy, changing demographies and increasing racial violence are brought to the sharp focus of the project. There for the On the Road project commenced as an interactive theatrical endeavour that investigates the manifold crises within communities.

On the Road, the one-woman performance series that Smith has been investigating, gathering, editing and performing since 1982, posits a radical challenge to the spectators to continuously relocate their ideological and critical positions. Smith reminiscences: "When I started this project in the early 1980s, my simple introduction to any one I interviewed was 'if you give me an hour of your time, I'll invite you to see yourself performed"(1993, xxiii). Through Smith's research and performance, the communities perceived its own frailties and obsessions with a sharp focus on the mimicking and mirroring aspects of the work.

Using the three questions devised by a linguist, Smith went to the streets to explore further the intricacies of human character revealed through the speech patterns of individuals. Smith's hypothesis on spoken word and its relationship to character found best manifestations when she had observed that the controlled and structured social identity revealed at the beginning of the interview process was subjected to a total subversion at certain moments. Such moments of subversive speech patterns emerge due to a special kind of energisation in speech. It results in unsophisticated, rigorous and performable expressions of the interviewee by rejecting the formalities of language. 
In the beginning of On the Road series, Smith performed in small communities, conference halls, lecture halls, rehearsal spaces, and classrooms elaborating issues within the community. These locations, generally non-theatrical spaces, hint at Smith's commitment to social action through theatrical devices. Moreover, these performances came out as a result of commissions by communities or institutions interested in self reflexive investigations of issues emanating within them. Usually Smith begins with a list of names and telephone numbers and then proceeds to links gathered from her subjects. She taped the interviews, edited them with great precision and presented before an audience including the interviewees.

On the Road: New York City produced for 'A Clear Space' Theatre, New York in 1982 , is the first among twenty one performances in the series so far. It is followed by $A$ Birthday Party and Aunt Julia's Shoes for Ward Nasse Gallery, New York in 1983 and Charlayne Hunter Gault in 1984. In her work Smith made use of some props and sets and a variety of telephones to suggest different characters in different locations. Smith performed with jackets, spectacles, hairstyles, coffee mugs and sandwiches to distinguish characters. Smith often shocks, delights, elevates and saddens the viewers by presenting words in rapid succession. In the beginning of On the Road series, Smith performed in small communities, conference halls, lecture halls, rehearsal spaces, and classrooms elaborating issues within the community. These locations, generally non-theatrical spaces, hint at Smith's commitment to social action through theatrical devices.

Smith's work in 1988 for 'Bay Area Women in Theatre' symposium organised by Phoenix Theatre, San Francisco, titled Voices of Bay Area Women has drawn its substance from people working in theatre. Smith's exploration of issues related to race and gender for University of Pennsylvania in Gender Bending: On the Road University of Pennsylvania, On Black Identity and Black Theatre for Cross Roads Theatre Company, New Brunswick and 
Fragments performed in the conference on intercultural performance in Bellagio, Italy are other instances from On the Road: A Search for American Character.

Gender Bending: Princeton University brought in issues such as how women were imported from Seven Sisters Colleges to Princeton campus to entertain men in the weekends, Sally Frank's version of the harassment she suffered when she sought admission to all male eating clubs and low paid black employees. In From the Outside Looking In performed for Eureka Theatre, San Francisco, Smith focused on the ethnic diversity of the Bay Area as the cause of its cultural and artistic renown. Her disturbing narratives on drugs being used by the state to criminalize the entire black community and on the discrimination of AIDS patients also had sprung the same notion.

In the early nineties, Smith's project gained abrupt public acclaim with her commission for the New York Public Theatre's 'Festival of New Voices' directed by George Wolfe. In the earlier works in On the Road series, Smith conducted her interview-based investigations within the communities and performed specifically for the community. Fires in the Mirror: Crown Heights Brooklyn and Other Identities is the first work she performed outside the locale of her investigations. Being a smashing commercial success, the performance was premiered in the New York Public Theatre and was later shifted to a larger theatre named Anspacher. In 1993, a television version of the performance was broadcast by the PBS American Play House. These performances marked a radical departure from Smith's earlier works in the series.

Twilight: Los Angeles 1992 is Smith's elegant performance piece based on the epidemic of riots in Los Angeles followed the verdict of the Rodney King beating case. After a nine-month long interview process, Smith presented characters belonging to various races, classes and locations in a distilled form in the Mark Taper forum, Los Angeles. The performance, a stunning documentary, portrays the first multi-cultural riot in America. The 
array of voices ranging from victims of violence, gang members, cops, looters, Korean merchants and public figures made the show compelling and extravagant. This performance does not attempt to address the origins of racial unrest in Los Angeles. Smith's effort in Twilight is to catch the essence of the ethnically diverse and divided city of Los Angeles.

House Arrest was an ambitious work that relocated and interrogated the praxis of power and mass media in the first world. The American Presidency and the controversial role of the press are debated by blending historical episodes, interviews, video and music with a strong desire to re-narrate American history. A variety of characters including presidents, media professionals, reporters, chefs and prison inmates were presented by a multi racial cast of twelve actors. White, African, American, Asian American and Latin performers enacted roles across the times of race, gender and age. To supplement the major issues of the work mediatisation and surveillance of the press - multimedia stage played a seminal role in House Arrest.

In a similar vein, the performative crossover of racial and ethnic identities unsettles the dominant discourses of race by contesting the historical positioning of racial identity. The visible markers such as different categories of colour and physiognomy are the key signifiers of racialised subjectivity. Racial theories are mostly built on the basis of practices of perception. But there are many black people who may pass for whites, but still be constructed as black. For instance, Anna Deavere Smith's tall, light skinned body lacks many visible signifiers of race. Therefore, it is evident that the production and regulation of subjects as essentially Black or White is a practice that emerges from the hegemonic discourse on race.

The racial and ethnic identities are performative like gender because they are also produced and legitimised by certain discursive regimes. The performativity of racial identity is inexplicably blended with representational practices of hegemonic culture. Subjects are 
racially positioned by a series of performances of race based on a combination of essentialist norms of the category of race such as skin colour, hair and physiognomy. Deconstruction of hegemonic practices of representation is a strategy to unsettle the boundaries of racial and ethnic identities. Elizabeth Abel's analysis of Tony Morrison's story "Recitatif" is an instance of how all readers identify with various racial positions in representation. Abel scrutinised the responses of Black and White readers of "Recitatif" in order to explicate the web of representational politics of race. Abel finds that the story defines race as a contested terrain "variously mapped from diverse positions in the social landscape"(471). Ambiguous social cues function as the markers of racial difference in "Recitatif".

Abel's reading of "Recitatif" problematises the politics of representing race. A rigorous move to de-essentialise racialised identity and the subsequent deconstruction of racial positioning in reading a text enable us to see the performativity of race in representation. Anna Deavere Smith invites the spectators to engage critically in the strategic positioning of racial, gender and ethnic identities in her performances. The cross-racial performances as well as cross-gender performances "can involve more crucially a deessentialising of identity, a shifting that throws into relief the shapings of identities through historically specific bodily disciplines that we label race, gender and so on" (Kondo 2000, 90). Such performances ostensibly present identities as performative. Smith's performative mimesis, as Elin Diamond suggests, is an effort to move beyond "the phenomenological universals of transcendent subjects and objects" to place identity in a more unstable and contingent relation to identification (Diamond 1992, 397). The spectator apparently engages in this process of locating identities as unstable and shifting in Smith's work both as a character performed on this stage and as spectator subject. The representation of identities in a fluid, unstable and transgressional manner in her performative unravelling of characters drawn from real life challenges the hegemonic practices of representation in culture. 
Smith's performative de-essentialising of identities and the consequent dismantling of the discursive regimes that constitute identities are immensely significant in the specific context of mainstream American Theatre, a pioneering domain of patriarchal domination of the White male. Smith in a letter to Dorinne Kondo, one of the dramaturges in her Twilight : Los Angeles 1992 project, expressed her disagreement with the representational practices of mainstream American Theatre:

As much as drama is defined as conflict, the American theater failed to take on the challenges of seeing and mirroring race conflict in our society...The theater as a cultural project in this country never really wrestled with the actor's body with all its racialised gestures and intonations, as evidence of racism and a racially divided society. (Kondo, D. 2000, 98)

A radical challenge to the representational politics of mainstream theatre is central to Smith's performative strategy of theatrical mimesis. Simultaneously Smith's works resist the essentialist identity politics of Black theatre and politics by exploring the subversive potential of representing identities. The constraints of theatrical identification around which the mainstream theatre perpetuates its racialised, gendered and ethnically specific stereotypes are constantly contested by Smith. She invokes repeatedly that the characters she perform are real life characters to evoke alienation effect among spectators in a Brechtian manner to challenge the matrix of identification. This effort is an unsettling of the pre-defined subject positions in the structure of 'Theatre'. Impersonation and mimicry are seminal to Smith's strategy of performative mimesis which acutely challenges the structures of conventional 'mimesis'. Her mimetic art, very much like her protean performance style which embodies subjects in a shifting, transgressing and fluid manner, has a seminal role in defining a radical performance practice. The spectators who are seeking 'authentic representation' of experience fail to capture the meaning of mimesis in Smith's work. Smith's mimetic 
performance art resists, challenges and even subverts the codes and conventions of representation facilitated by dominant social and cultural systems. This performance practice contests and consequently rejects the possibilities of 'authentic' representation.

'Mimesis' always points to the absented presence of a 'true real'. Psychoanalyst and Feminist, Luce Irigaray interrogated the authenticity of the 'true real' which perpetuated the patriarchal notion of truth through epistemological, ontological and metaphorical discourses. Irigaray's reading of Plato's cave as a theatre explains 'mimesis' as an attempt to maintain a fixed and monolithic truth. She observed in Plato's condemnation of 'mimesis, an attempt to control the proliferation of alternatives in an effort to bring in a stable and monolithic patriarchal truth. Irigaray favours 'mimicry' because the multiple and excessive representations in mimicry will undo the monolithic and fixed patriarchal truth.

Simultaneously such mimetic practices as opposed to Plato's concept of 'mimesis' destabilise the "idea of essence, truth and origin" by displacing continually these norms "onto a question of material relations and operations" as Elin Diamond suggests. $(1989,65)$ In order to resist the imposition of patriarchal truth through mimesis, Irigaray proposes 'mimicry', a multiple and excessive mimetic practice, which undermines the unique claim of patriarchal truth. She invents that mimicry as a mimetic act has a radical potential, especially in the context of feminist performance art by defining it as a process of resubmitting woman's identity to stereotypical views in order to call the views themselves into question. The repetitive performances involved in mimicry are not enacted faithfully.

Anna Deavere Smith excels in bringing out the dismantling potential of mimicry through her mimetic performances by interrogating 'authentic representation' as a realm of patriarchal truth and hegemony. Mimesis in Smith's hands is a performative strategy very much like 'mimicry' which relies on performing multiplicity of actualities simultaneously by putting into question the single, monolithic and authentic 'real'. This practice of challenging 
and subverting the notion 'true real' by means of performing real life characters ultimately results in unsettling the representations of dominant culture.

A summate subversion of hegemonic cultural norms and the canon of visual culture, in favour of a radical, counter cultural strategy of representation is the hallmark of Smith's performance project. Smith locates her characters exactly in the matrices of history and power so that her mimesis in documentary format has become a process of making visible the apparently invisible and inconceivable in the quarters of high art and popular culture. 


\section{Bibliography}

Abel, Elizabeth. 1993. "Black Writing, White Reading: Race and the Politics of Feminist Interpretation." Critical Inquiry Spring. 471- 498.

Butler, Judith. 1990. Gender Trouble: Feminism and the Subversion of Identity. New York:

Routledge.

--- . 1996. Bodies That Matter: On the Discursive Limits of Sex. New York: Routledge.

Caillois, Roger. 1961 Man, Play and Games New York: The Free Press.

Carlson, Marvin. 1996 Performance: A Critical Introduction New York: Routledge.

--- . 1984 Theories of the Theatre Ithaca: Cornell University Press.

De Certeau, Michael. 1984 The Practice of Everyday Life. Trans. Stephan. R. Rendall.

Berkeley and Los Angeles: University of California Press.

Derrida, Jacques. 1978 Spurs/Nietzsche’s Styles Trans. Barbara Harow. Chicago: University of Chicago Press.

--- . 1978a. "The Thearer fo Cruelty and the Closure of Representation," Writing and Difference. Trans. Alan Bass, Chicago: University of Chicago Press. 232-50.

Diomond, Elin. 1989. "Mimesis, Mimicry and the True Real” Modern Drama. Vol. 32 59-60

--- . 1992. “The Violence of 'We': Politicizing Identification” in Critical Theory and Performance. Eds. Jenelle Reinelt and Joseph Roach. Ann Arbour, University of Michigan Press.

Dolan, Jill. 1996. "In Defence of Discourse...." Ed. Carol Martin. A Source Book of Feminist Theater and Performance. New York: Routledge, 95- 107.

Dyre, R. 1977. White. London: Routledge.

Ferris, Lesley. Ed. 1989. Acting Women: Images of Women in Theater New York: NewYork University Press. 
Forte, Jeanie 1988. “Women's Performance Art: Feminism and Postmodernism” Theatre Journal. March

Gates, Henry Louis. 1985 'Race’ Writing and Difference. Chicago: The University of Chicago Press.

Gilroy, Paul. 1993. The Black Atlantic: Modernity and Double Consciousness. Cambridge: Harvard University Press.

Goffman, Erving. 1959. The Presentation of Self in Everyday Life. New York: Anchor Books, Doubleday.

Hooks, bell. 1990. Yearning. Boston, MA: South End Press.

--- . 1995. Art on My Mind. New York: The New Press.

Irigaray, Luce. 1985. The Sex Which is Not One. Tr. Catherine Porter. Ithaca: Cornel University Press.

Jones, Amelia. 1998. Body Art: Performing the Subject . Minneapolis: University of Minnesota Press.

Kershaw, Baz. 1999. The Radical in Performance : Between Brecht and Baudrillard. New York: Routledge.

Kondo, Dorinne.1997. About Face: Performing Race in Fashion and Theatre. New York: Routledge.

--- . 2000. “(Re)Visions of Race: Contemporary Race Theory And the Cultural Politics of Racial Crossover in Documentary Theatre.” Theatre Journal Vol.52 .1.

Lyons, Charles. R and James. C. Lyons. 1994. “Anna Deavere Smith: Perspectives on Her Performance within the Context of Critical Theory." Journal of Dramatic Theory and Criticism. Fall.

Mama, Amina. 1995. Beyond the Masks : Race, Gender and Subjectivity.London: Routledge. 
Martin Carol.1996. "Bearing Witness.” In Ed. Carol Martin. A Source Book of Feminist Theatre and Performance. New York: Routledge.

Modlesky, Tania 1997. "Doing Justice to The Subjects" Ed. Abel, Elizabeth et. al Female Subjects in Black and White: Race, Psychoanalysis and Feminism. Berkeley:

University of California Press

Montano, Linda. 1981. Art in Everyday Life Los Angeles: Astro Artz.

Pellegrini, Ann 1997. Performative Anxieties: Staging Psychoanalysis, Staging Race. New York: Routledge.

Phelan, Peggy. 1993. Unmarked: Politics of Performance. London: Routledge.

Richards, Sandra. L.1993. "Caught in the Act of Social Definition: On the Road with Anna Deavere Smith.” In Eds. Lynda Hart and Peggy Phelan Acting Out: Feminist Performances. Ann Arbor: University of Michigan Press.

Schechner, Richard. 1967. "Public Events for the Radical Theatre," The Village Voice, September 7.

--- . 1999. “Anna Deavere Smith: Acting As Incorporation” In Ed. Anne Marie Bean. A Source Book of African American Performance. New York: Routledge.

Smith, Anna Deavere. 1992. 1993. Fires in the Mirror: Crown Heights Brooklyn and Other Identities New York: Doubleday.

--- . 1994. Twilight : Los Angels, 1992. New York. Anchor Books Doubleday.

--- . 2000. House Arrest. Manuscript from Smith's Personal Collection.

--- . 2000a. Talk To Me: Listening Between the Lines New York: Random House. Ugwu, Catherine.1995. Let's Get it On. Seattle, W.A: Bay Press. 